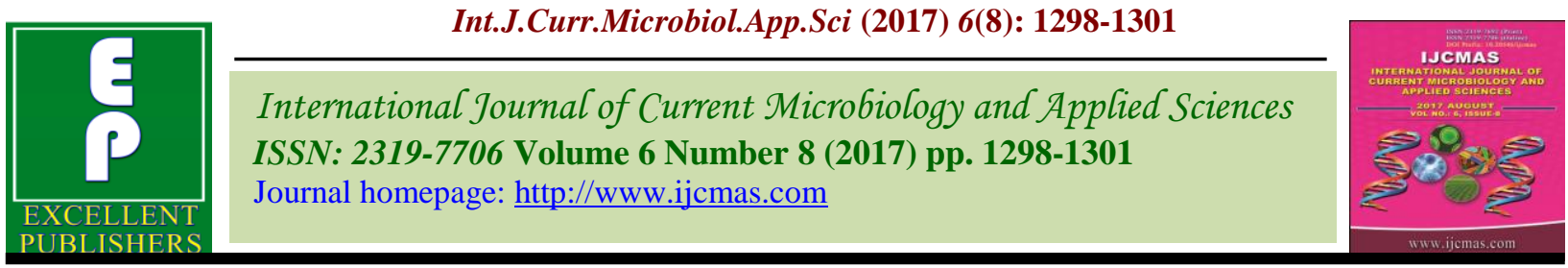

Original Research Article https://doi.org/10.20546/ijcmas.2017.608.157

\title{
In vitro Efficacy of Fungicides against Dry Root Rot (Macrophomina phaseolina) of Soybean
}

\author{
Dinesh H. Chaudhary ${ }^{1^{*}}$, D.M. Pathak ${ }^{2}$ and Mahesh M. Chaudhary ${ }^{1}$ \\ ${ }^{1}$ Department of plant pathology, N. M. College of Agriculture, India \\ ${ }^{2}$ Department of plant pathology, College of Agriculture Bharuch, Navsari Agricultural \\ University, Navsari, Gujarat-396 450, India \\ *Corresponding author
}

\section{A B S T R A C T}

\begin{tabular}{|l|l|l|l}
\hline Keywords & $\begin{array}{l}\text { Chemical control is one of the measures to manage the disease and avoid } \\
\text { the losses. The evaluation study was therefore conducted in vitro. Ten } \\
\text { In vitro, }\end{array}$ \\
$\begin{array}{l}\text { fungicides, } \\
\text { Soybean. }\end{array}$ & $\begin{array}{l}\text { in vitro. The highest inhibition }(100 \%) \text { of } M \text {. phaseolina } \text { was observed due } \\
\text { to carbendazim } 50 \% \mathrm{WP} \text { at different concentration }(250,500,1000 \mathrm{ppm}), \\
\text { mancozeb } 75 \% \mathrm{WP}(1500,2000,2500 \mathrm{ppm}), \text { ridomil-MZ } 72 \% \mathrm{WP}(1000,\end{array}$ \\
\cline { 1 - 1 } $\begin{array}{l}1500,2000 \mathrm{ppm}) \text { and carbendazim } 12 \%+\text { mancozeb } 63 \%(1500,2000, \\
\text { Accepted: } \\
17 \text { June } 2017 \\
\text { Available Online: } \\
10 \text { August } 2017\end{array}$ & $\begin{array}{l}2500 \mathrm{ppm}) \text { followed by propiconazole at } 250 \mathrm{ppm}(87.21 \%), 500 \mathrm{ppm} \\
(89.92 \%) \text { and } 1000 \mathrm{ppm}(92.64 \%) \text { and rest of the treatments significantly } \\
\text { inhibited colony growth over control. }\end{array}$ \\
\hline \hline
\end{tabular}

\section{Introduction}

Oilseed crops have been the backbone of agricultural economy of India from time immemorial. Soybean is considered as the wonder legume because none of the other crops has multipurpose utilization.

It occupies an intermediate position between legumes and oil seed, containing in more protein $(40 \%)$ then most of the legumes, but less oil $(20 \%)$ then majority of the oil seed. Among all the oil seed crops, soybean is the most nutritive as it contains maximum lysine (64\%). Above 40 per cent of the world supply of edible vegetable oil comes from soybean. In India diseases play an important role in Soybean cultivation and responsible to cause
25-60 per cent yield losses every year. In India, soybean is a known to be attacked by several diseases viz., wilt (Fusarium solani Mart. Sacc.), Anthracnose (Colletotrichum dematium Pers. Fr.), Sclerotium rot (Sclerotium rolfsii Sacc.), Dry root rot (Macrophomina phaseolina (Tassi.) Goid) among these, dry root rot caused by Macrophomina phaseolina (Tassi.) Goid is an important one. M. phaseolina (Tassi.) Goid is reported to be soil, seed and stubble borne fungus. The pathogen $M$. phaseolina generally affects the fibro vascular system of the roots and basal internodes affect the transport of nutrients and water to the upper parts of the plant. 


\section{Materials and Methods}

The diseased samples were collected from College Research Farm, NAU, Navsari as well as farmers field during 2016. Affected plant of soybean showing typical dry root rot symptoms. The infected samples were brought to the laboratory and subjected to microscopic examination and tissue isolation.

The portion of the roots affected by root rot disease was cut into $5 \mathrm{~mm}$ small pieces. These pieces were then surface sterilized in 0.1 per cent mercuric chloride solution $\left(\mathrm{HgC}_{12}\right)$ followed by three changes in sterile water. Then these pieces were planted on sterilized Potato dextrose agar (PDA) in Petri dishes. The Petri dishes were incubated at $28 \pm 2{ }^{\circ} \mathrm{C}$ temperature in inverted position. After 3 days, sub culturing was done on Potato dextrose agar slants by transferring the young mycelial bit with the help of sterile inoculating needle. The culture tubes were kept at $28 \pm 2^{\circ} \mathrm{C}$ temperature throughout the course of studies. Sub culturing was done at regular intervals of 15 days, using Potato dextrose agar slants. Potato dextrose agar medium was used as a basal medium for the fungicidal study by Poisoned food technique.

Potato dextrose agar medium was prepared in the $250 \mathrm{ml}$ conical flask. $100 \mathrm{ml}$ medium was taken in each flask. The medium then was sterilized at $15 \mathrm{lbs}$ vapour pressure for 15 minutes. Required quantity of test fungicides were calculated and added in the sterilized medium separately. Flasks containing poisoned medium were shaken well to have even and uniform distribution of the fungicides. About $20 \mathrm{ml}$ of poisoned PDA was poured in each of the sterilized Petri plates and allowed to solidify. The plates were inoculated by pure culture of Macrophomina phaseolina. For this purpose, $5 \mathrm{~mm}$ disc of one week old culture was cut with a sterilized cork borer. The disc was lifted and transferred aseptically in the centre of Petri plates containing the medium with test fungicides. Three plates were maintained for each treatment. The control plates without fungicides were also inoculated and kept for incubation. Treated plates were incubated at $28 \pm 2^{\circ} \mathrm{C}$ temperature. The observations on colony diameter were recorded after 5 days. The inhibition zone was calculated by using the following formula.

Grow th inhibition $(\%)=\frac{\mathrm{C}-\mathrm{T}}{\mathrm{C}} \times 100$

Where,

$\mathrm{C}=$ Growth of pathogen in control after incubation

$\mathrm{T}=$ Growth of pathogen in treatment after incubation

The data were statistically analysed in C.R.D

\section{Results and Discussion}

Among ten fungicides were evaluated at three different concentrations by poisoned food technique against M. phaseolina.

The results are presented in table 1, indicated that all fungicides evaluated significantly reduced the growth of $M$. phaseolina as compare to control but all the fungicides and their concentrations significantly differ within themselves. Among all concentration, the higher concentration of each fungicide produced maximum growth inhibition of the pathogen. From fungicides, mancozeb $75 \%$ WP, carbendazim $50 \% \mathrm{WP}$, ridomil-MZ 72 $\%$ WP and carbendazim $12 \%+$ mancozeb 63 $\%$ at all the three concentration completely inhibited growth of the pathogen.

The next best in order of merit were propiconazole at $250 \mathrm{ppm}(87.21 \%), 500$ ppm (89.92\%) and $1000 \mathrm{ppm}(92.64 \%)$ followed by trifloxystrobin $25 \%+$ 
tebuconazole $50 \%$ at $500 \mathrm{ppm}(79.84 \%)$, $1000 \mathrm{ppm}(83.72 \%)$ and $1500 \mathrm{ppm}(86.82$ $\%$ ), benomyl $50 \% \mathrm{WP}$ at $250 \mathrm{ppm}(73.64 \%)$, $500 \mathrm{ppm}(79.84 \%)$ and $1000 \mathrm{ppm}(82.56 \%)$, chlorothalonil at $1500 \mathrm{ppm}(74.03 \%), 2000$ ppm (77.13 \%) and 2500 ppm (79.07 \%), copper oxychloride at $1500 \mathrm{ppm}$ (68.99\%) $2000 \mathrm{ppm}(69.77 \%)$ and $2500 \mathrm{ppm}(72.87$ $\%$ ), kresoxin methyle $50 \% \mathrm{SC}$ at $250 \mathrm{ppm}$ (57.36\%), $500 \mathrm{ppm}(63.95 \%)$ and $1000 \mathrm{ppm}$ $(65.89 \%)$ inhibiting the growth of $M$. phaseolina.

Table.1 Evaluation of different fungicides against Macrophomina phaseolina in vitro

\begin{tabular}{|c|c|c|c|c|}
\hline Treat. & Fungicides & $\begin{array}{c}\text { Concentration } \\
(\mathbf{p p m})\end{array}$ & $\begin{array}{c}\text { Average Colony diameter } \\
\text { of pathogen }(\mathbf{m m})\end{array}$ & $\begin{array}{c}\text { Growth inhibition over } \\
\text { control (\%) }\end{array}$ \\
\hline \multirow{3}{*}{$\mathrm{T}_{1}$} & \multirow{3}{*}{ Mancozeb 75\% WP } & 1500 & $0.71 *(0)$ & 100 \\
\hline & & 2000 & $0.71(0)$ & 100 \\
\hline & & 2500 & $0.71(0)$ & 100 \\
\hline \multirow{3}{*}{$\mathrm{T}_{2}$} & \multirow{3}{*}{ Copper oxychloride $50 \% \mathrm{WP}$} & 1500 & $5.21(26.7)$ & 68.99 \\
\hline & & 2000 & $5.15(26)$ & 69.77 \\
\hline & & 2500 & $4.9(23.3)$ & 72.87 \\
\hline \multirow{3}{*}{$\mathrm{T}_{3}$} & \multirow{3}{*}{ 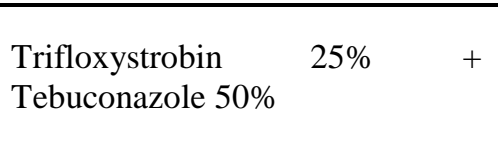 } & 500 & $4.22(17.3)$ & 79.84 \\
\hline & & 1000 & $3.80(14)$ & 83.72 \\
\hline & & 1500 & $3.45(11.3)$ & 86.82 \\
\hline \multirow{3}{*}{$\mathrm{T}_{4}$} & \multirow{3}{*}{ Chlorothalonil 75\% WP } & 1500 & $4.78(22.3)$ & 74.03 \\
\hline & & 2000 & $4.49(19.7)$ & 77.13 \\
\hline & & 2500 & $4.30(18)$ & 79.07 \\
\hline \multirow{3}{*}{$\mathrm{T}_{5}$} & \multirow{3}{*}{$\begin{array}{l}\text { Carbendazim } 12 \%+\text { Mancozeb } \\
63 \% \text { WP }(75 \%)\end{array}$} & 1500 & $0.71(0)$ & 100 \\
\hline & & 2000 & $0.71(0)$ & 100 \\
\hline & & 2500 & $0.71(0)$ & 100 \\
\hline \multirow{3}{*}{$\mathrm{T}_{6}$} & \multirow{3}{*}{ Kresoxim methyl $50 \mathrm{SC}$} & 250 & $6.10(36.7)$ & 57.36 \\
\hline & & 500 & $5.61(31)$ & 63.95 \\
\hline & & 1000 & $5.46(29.3)$ & 65.89 \\
\hline \multirow{3}{*}{$\mathrm{T}_{7}$} & \multirow{3}{*}{ Benomyl 50\% WP } & 250 & $4.81(22.7)$ & 73.64 \\
\hline & & 500 & $4.22(17.3)$ & 79.84 \\
\hline & & 1000 & $3.94(15)$ & 82.56 \\
\hline \multirow{3}{*}{$\mathrm{T}_{8}$} & \multirow{3}{*}{ Carbendazim 50\% WP } & 250 & $0.71(0)$ & 100 \\
\hline & & 500 & $0.71(0)$ & 100 \\
\hline & & 1000 & $0.71(0)$ & 100 \\
\hline \multirow{3}{*}{$\mathrm{T}_{9}$} & \multirow{3}{*}{ Propiconazole $25 \%$ EC } & 250 & $3.39(11)$ & 87.21 \\
\hline & & 500 & $3.02(8.7)$ & 89.92 \\
\hline & & 1000 & $2.61(6.3)$ & 92.64 \\
\hline \multirow{3}{*}{$\mathrm{T}_{10}$} & \multirow{3}{*}{$\begin{array}{l}\text { Metalaxyl } 8 \%+\text { Mancozeb } 64 \% \text {, } \\
\text { (72\% WP) }\end{array}$} & 1000 & $0.71(0)$ & 100 \\
\hline & & 1500 & $0.71(0)$ & 100 \\
\hline & & 2000 & $0.71(0)$ & 100 \\
\hline$\overline{T_{11}}$ & Control & - & $9.30(86)$ & 000 \\
\hline \multicolumn{2}{|l|}{ S.Em. \pm} & - & 0.08 & - \\
\hline \multicolumn{2}{|c|}{ C.D. at $5 \%$} & - & 0.24 & - \\
\hline \multicolumn{2}{|l|}{ C.V.\% } & - & 4.64 & - \\
\hline
\end{tabular}

Mean of three repetitions

*Figures are $\mathrm{SQR}+0.5$ transformed values

Figures in parenthesis are original values 
Experiment details

\begin{tabular}{|l|l|}
\hline a) Design & Completely Randomized Design (CRD) \\
\hline b) Repetitions & $3($ Three) \\
\hline c) Treatments & 11 (Eleven) \\
\hline d) Method & Poisoned food technique \\
\hline
\end{tabular}

It is evident from the results that the growth inhibition of $M$. phaseolina increased as increase in the concentration of the chemicals. Mancozeb 75\% WP, carbendazim 50\% WP, carbendazim 12\% + mancozeb $63 \%$ and metalaxyl $8 \%+$ mancozeb $64 \%, 72 \% \mathrm{WP}$ were proved most effective.

Lambhate et al., (2002) tested the efficacy of fungicides against $M$. phaseolina, root rot pathogen of cotton in vitro and reported that bavistin, ridomil M Z-72 and topsin-M at 0.1, 0.2 and 0.3 per cent showed cent per cent inhibition of mycelial growth of the fungus. Khalikar et al., (2011) reported that carbendazim 50\% WP @ 2g/kg, were superior in reducing pre and post emergence seedling rot and root rot disease $(M$. phaseolina) of cluster bean.

\section{References}

Chattopadhyay, C. and Sastry, R. K. (2002). Combining viable disease control tools for management of sesame stem root rot caused by $M$. phaseolina. Indian $J$. Plant Prot., 30: 132-138.

Jaiman, R. K.; Jain, S. C. and Sharma, P. (2009). Field evaluation of fungicides, bioagents and soil amendments against root rot caused by Macrophomina phaseolina in cluster bean. J. Mycol. Pl. Pathol., 39: 74-76.
Jha, K. M. and Sharma, N. D. (2006). Studies on factors affecting Rhizoctonia bataticola. IV. Fungicide. $J$. Mycopathol. Res., 44: 67-71.

Khalikar, P. V.; Gholve, V. M. and Adsul, A. $\mathrm{K}$. (2011). In vitro management of Mcrophomina phaseolina by chemicals. International Journal of Plant Protection, 4: 201-203.

Lambhate, S. S.; Chaudhari, G. K.; Mehetre, S. S. and Zanjare, S. R. (2002). In vitro evaluations of chemicals against root rot of cotton caused by $M$. phaseolina. $J$. Maharashtra Agril. Uni, 21: 99-100.

Moradia, A. M. (2011). Management of Macrophomina phaseolina in groundnut through systemic fungicides. Internat. $J$. Agric. Sci., 4: 212-213.

Nagamma, G.; Saifulla, M. and Narendrappa, T. (2012). In-vitro Evaluation of Fungicides, Bioagents and Botanicals against Macrophomina phaseolina (Tassi) Goid the Causal agent of Dry Root Rot in Chickpea. Mysore J. Agric, Sci., 46: 778-783.

Suryawanshi, A. P.; Gore, D. D.; Gawande, D. B.; Pawar, A. K. and Wadje, A. G. (2008). Efficacy of fungicides against Macrophomina blight of mung bean. $J$. Pl. Dis. Sci., 3: 40-42.

Tonin, R.; Fatima, B. Avozani, A. (2013). Efficacy fungicide against $M$. Phaseolina in cotton. Agropec. Trop., 43: 460-466.

\section{How to cite this article:}

Dinesh, H. Chaudhary, D.M. Pathak and Mahesh M. Chaudhary. 2017. In vitro Efficacy of Fungicides against Dry Root Rot (Macrophomina phaseolina) of Soybean. Int.J.Curr.Microbiol.App.Sci. 6(8): 1298-1301. doi: https://doi.org/10.20546/ijcmas.2017.608.157 